\title{
DETECTION AND SPATIAL ANALYSIS OF LAND-USE: A CASE OF BUTUAN CITY WITH HISTORY OF MAJOR INFORMAL SETTLEMENTS
}

\author{
LC. S. Asube ${ }^{1,2}$, J. M. Daquiado ${ }^{2}$, BJ. P. Lavapiz ${ }^{2}$
}

\begin{abstract}
${ }^{1}$ Caraga Center for Geo-Informatics, Caraga State University, Ampayon, Butuan City, 8600, Philippines - lsasube@ carsu.edu.ph
${ }^{2}$ Department of Geodetic Engineering, College of Engineering and Geosciences, Caraga State University, Ampayon, Butuan City, 8600, Philippines - (joyjiedaquiado123, byrnejunlavapiz123)@gmail.com
\end{abstract}

KEY WORDS: Informal Settlements, Land-use, Support Vector Machine, Geographic Information System, Remote Sensing, Thematic Map

\begin{abstract}
:
This study detects the significant informal settlements in Butuan City proper. It determines the growth rate in 15 years with the given five-year interval. Machine learning algorithms and spatial analysis were applied to obtain the possible locations of informal settlement buildings. The projected locations of informal settlement buildings were validated thru aerial image validation using Remote Sensing and GIS-based techniques in ArcGIS software. Eight (8) barangays satisfy all the informal settlement building characteristics during the aerial validation process and ground-truthing, namely, Golden Ribbon, Holy Redeemer, Limaha, New Society, Ong Yiu, Port Puyohon, San Ignacio, and Tandang Sora. The eight (8) barangays were manually digitized from the given 5-years interval from 2005, 2010, 2015, and 2010. The value of the major informal settlement buildings area was computed to excel. The area growth rate was calculated using the growth rate formula. This study showed that the significant informal settlement in the study area increased. Among the eight (8) focused barangays, Tandang Sora ranked the highest informal settlements growth from 2005 to 2020 . Its area increases up to $178.52 \%$, a total of $24,608.43$ square meters. Finally, the results revealed that the area of informal settlement buildings in Butuan City from 2005-2020, in 15-years, its value increases up to $9.74 \%$, a total of $19,172.88$ square meters.
\end{abstract}

\section{INTRODUCTION}

In most developing countries, informal settlements are such a great feature in towns and cities. The most common ones are slums and squatters. The land is scarce, and urban land becomes even more. Squatting and lack of access to land is one of the most challenging factors for the urban poor. Many people in developing countries must find shelter in the market. The public sector cannot offer affordable land or housing. With this, policies are there to reduce the informal settlements, but still a failure. The trend is rising. Now, over-urbanization has become a big problem (Huerta, 2019).

In the Philippines, urbanization is rising, and one of the prominent aspects of this is informal settlements. They have become a national problem because it is expanding. The vacant lands owned by the government along coasts, riverbanks, creeks illegally claim both publicly and privately owned property (Asm Amanullah, 2011). These people claiming these properties are informal settlers because they live in lands without the consent of the property owners or the government. They lived in dangerous areas such as railways or even under bridges. Some of them lived in government infrastructure projects; protected/forest areas (except for indigenous peoples), lands for Priority Development (APDs), other government/public lands, or facilitation households with the status rent-free without permission from owners. In the province of Agusan del Norte, informal settlers account for 58 percent and 85 percent of Butuan City households (Navarro et al., 2014)

The objective of this study is to detect the land use with prominent informal settlers in Butuan City. It also aims to utilize a machine-learning algorithm to detect informal settlement areas in Butuan City and produce maps of central informal settlement area locations.
This study is beneficial to the government of Butuan City in assessing the situations of the informal settlers who frequently live in dangerous locations in the most environmentally and geographically hazardous areas. Thus, the study played an essential role in the development planning in the city to detect and map the informal settlers.

\section{METHODS}

\subsection{Data Acquisition}

Data acquisition involves gathering information on the informal settlers, including readily available datasets from appropriate offices, internet downloadable data, and other reliable sources.

\section{2 nDSM Generation}

Digital Terrain Model (DTM) (Baghdadi, Zribi, 2017) and Digital Surface Model (DSM) were requested to the Caraga Center for Geo-informatics (CCGeo). These data were used to generate nDSM or Normalized Digital Surface Model for getting the elevation of features within the study area using ArcGis software.

\subsection{Segmentation}

Segmentation is commonly used to separate more important things, such as objects, into smaller segments. In eCognition Developer, segmentation is any process that produces new picture objects or changes the morphology of existing image objects based on specific criteria. It means that segmentation can be subdividing, merging, or reshaping (Baatz et al., 2001). 


\subsection{Classification}

The Classification algorithm uses class descriptions to categorize picture objects. It examines the class description to see if an image object may be a member of a class. Without a class description, classes are considered to have a membership value of one (Baatz et al., 2001).

\subsection{Downloading Satellite Data}

Google Earth satellite imagery was downloaded for the study area. Four (4) different year images with five-year intervals were downloaded in 2005, 2010, 2015, and 2020.

\subsection{Image Rectification}

Using ArcMap 10.8 software, the correct coordinates of downloaded satellite imagery have been set using the georeferencing tool.

\subsection{Spatial Analysis}

The spatial analysis process was used to validate the focused area using satellite imagery from 2020 google earth imagery. It was composed of aerial image validation and ground-truthing. Thru this process, the researcher can quickly identify whether the projected areas were building or vegetation. Furthermore, additional parameters are being applied by manual aerial image validation. The physical characteristics of the informal settlement are derived through visual interpretation, integrated, and combined with GIS analysis of the provided dataset. In determining the necessary information to describe informal settlement, visual interpretation of the image and review of various literature was made to develop indicators specific to local conditions.

\subsection{Image Digitation in ArcGis}

Digitizing in GIS is converting geographic data either from a hardcopy or a scanned image into vector data by tracing the features. During the digitizing process, features from the traced map or image are captured as coordinates in either point, line, or polygon format. Manual digitizing was performed on the projected prominent informal settler to calculate the area's growth using four different images from Google Earth 2005, 2010, 2015, and 2020. The digitized area calculation was performed in excel, and the growth rate percentage was calculated using Equation 1 (Patrick Campbell, 2020).

\subsection{Infrastructure Growth Rate (IGR) Statistical Method}

The digitized area calculation was performed in excel, and the growth rate percentage was calculated using Equation 1

Growth Rate $=($ Vpresent-Vpast $)) /$ Vpast $x 100$

$$
\text { Growth Rate }=\frac{\text { Vpresent }- \text { Vpast }}{\text { Vpast }} \times 100
$$

where: $\quad$ Vpresent $=$ present value

Vpast $=$ past value

\subsection{Aerial Image Validation}

Aerial image validations were used to validate the support vector machine algorithm projected informal settlements results in Ecognition developer. In visually identifying the non-building and building, other informal settlement characteristics (Table 1) were considered during the process. The results of the Support Vector Machine (SVM) algorithm in identifying the informal settlements are mainly projected in this area. The areas were validated through aerial image validation in visual interpretation of the image and review of various literature to identify the other aspect qualified as informal settlements. The visual interpretation of aerial images is not automated. However, it requires expert knowledge, systematic search, and additional data to ensure adequate identification of the target features.

Typically, the informal settlements in Butuan are characterized by the following properties (through visual interpretation):

1. Rectangular and elongated single-storied buildings

2. Simple geometry: Most of the roofs are 4-sided.

3. Most of the roofs are constructed with uneven textures. The color of the roofs occurs mostly bright grey to bright blue and in some bright red to dark brown; and

4. Irregular patterns of buildings without any ordered orientation.

\begin{tabular}{|l|l|c|}
\hline \multicolumn{1}{|c|}{$\begin{array}{c}\text { Image } \\
\text { Observation }\end{array}$} & $\begin{array}{l}\text { Knowledge from } \\
\text { experts }\end{array}$ & Indicators \\
\hline $\begin{array}{l}\text { Buildings range } \\
\text { from bright grey } \\
\text { to dark brown } \\
\text { and red }\end{array}$ & $\begin{array}{l}\text { Majority of roofs } \\
\text { constructed from } \\
\text { galvanized iron } \\
\text { sheets, or tin }\end{array}$ & Spectral \\
\hline $\begin{array}{l}\text { Rectangular and } \\
\text { elongated shape, } \\
\text { varying building } \\
\text { size; }\end{array}$ & $\begin{array}{l}\text { Rental houses - } \\
\text { many units in a } \\
\text { single building; }\end{array}$ & \\
\hline $\begin{array}{l}\text { Irregular } \\
\text { orientation and } \\
\text { shape }\end{array}$ & $\begin{array}{l}\text { Builthaphazardly } \\
\text { due to lack of } \\
\text { planning }\end{array}$ & Shape/ \\
\hline $\begin{array}{l}\text { Settlements in } \\
\text { black soil, } \\
\text { unpaved roads }\end{array}$ & $\begin{array}{l}\text { Dwellings } \\
\text { located in flood- } \\
\text { prone areas }\end{array}$ & Association \\
\hline $\begin{array}{l}\text { Variable } \\
\text { densities }\end{array}$ & $\begin{array}{l}\text { Density higher } \\
\text { than planned } \\
\text { areas }\end{array}$ & Texture \\
\hline
\end{tabular}

Table 1. Visual observation and expert knowledge of image-based indicators

\subsection{Ground Truthing}

Location of the informal settlement in eight (8) barangays namely; Golden Ribbon, Holy Redeemer, Limaha, New Society, Ong Yiu, Port Puyohon, San Ignacio, and Tandang Sora. They were identified based on the SVM algorithm. The following informal settlements areas were digitized manually and were first validated using aerial image validation. The extent of the settlement was used as a reference in ground truth data collection. 


\section{RESULTS AND DISCUSSION}

\subsection{Informal Settlement Area Map using Support Vector} Machine (SVM) Algorithm

Figure 1 shows the map of the area using the Support Vector Machine (SVM) classification algorithm in E-cognition developers. Projection of the informal settlement buildings through the algorithm condition that the Formal Housing Concepts site all buildings for informal settlements study. It has $2.75 \mathrm{~m}$ in height from the ground, which is one of the characteristics of informal settlement buildings. From the classification result, only eight (8) barangays in Butuan City proper projected a major informal settlement, namely, Golden Ribbon, Holy Redeemer, Limaha, New Society, Ong Yiu, and Port Puyohon, San Ignacio, and Tandang Sora. The said barangays were subjected to aerial object-oriented image analysis and ground-truthing.

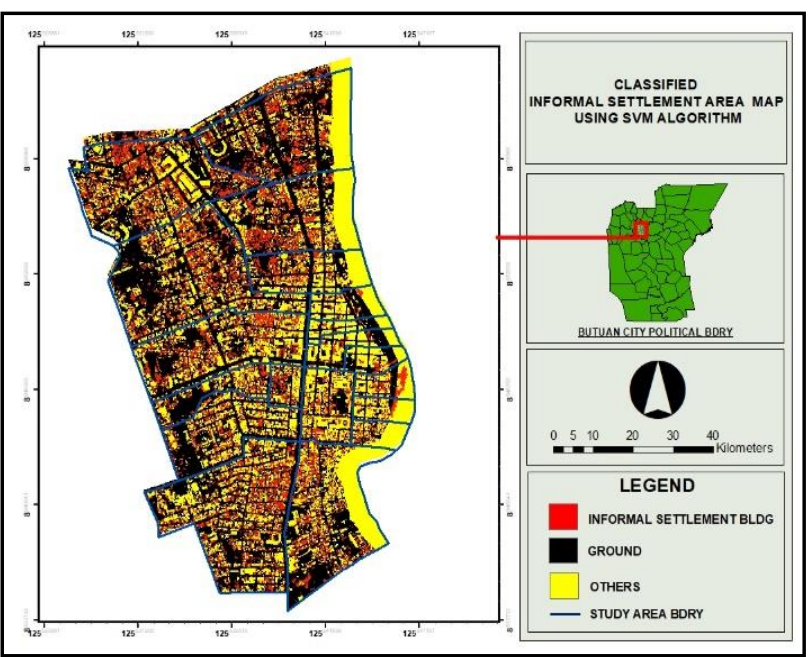

Figure 1. Classified Informal Settlement Area Map using SVM Algorithm

\subsection{Classified Area as Informal Settlements}

The informal settlement location was identified using a support vector machine algorithm and spatial analysis. Figure 2 to Figure 9 shows the digitized location of informal settlements of eight barangays. These locations were validated through groundtruthing and random interviews with the residents. Field validation and interviews reveal that private individuals claimed most of the detected informal settlements area.

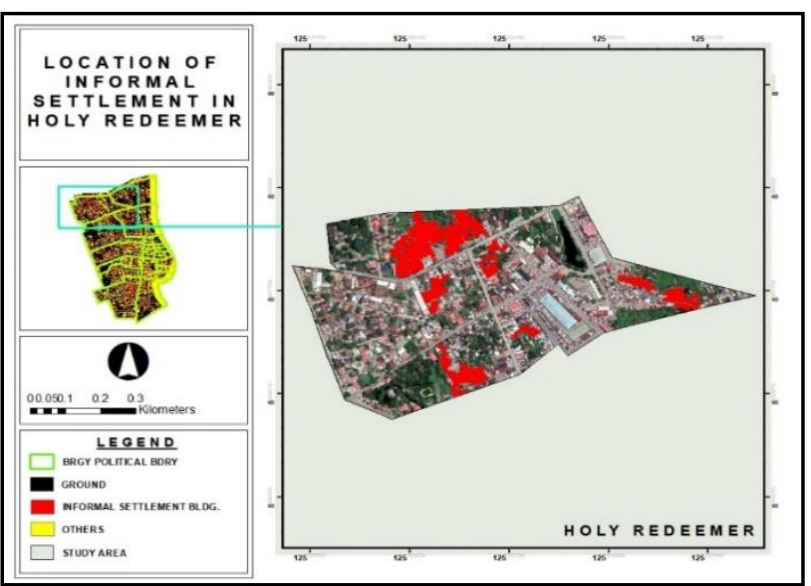

Figure 2. Informal Settlement in Brgy. Holy Redeemer

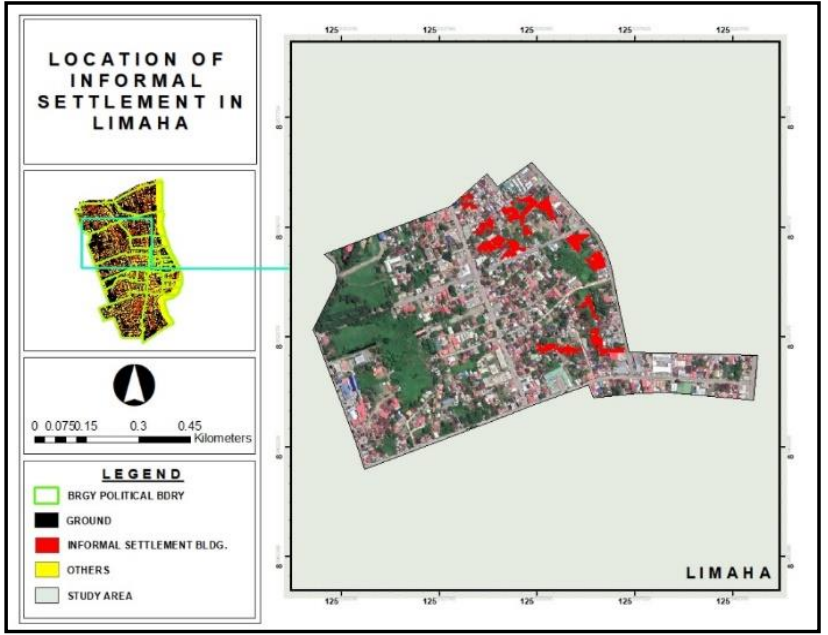

Figure 3. Informal Settlement in Brgy. Limaha

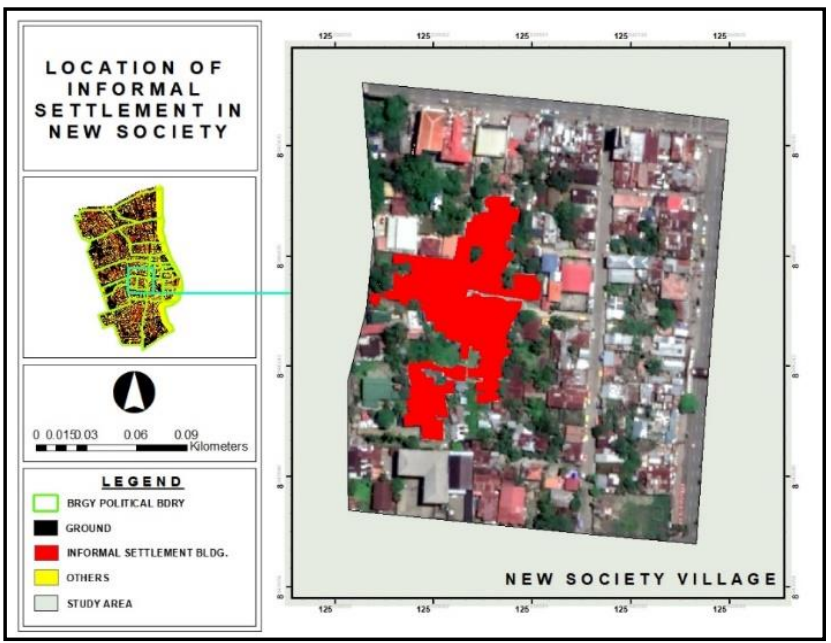

Figure 4. Informal Settlement in Brgy. New Society Village

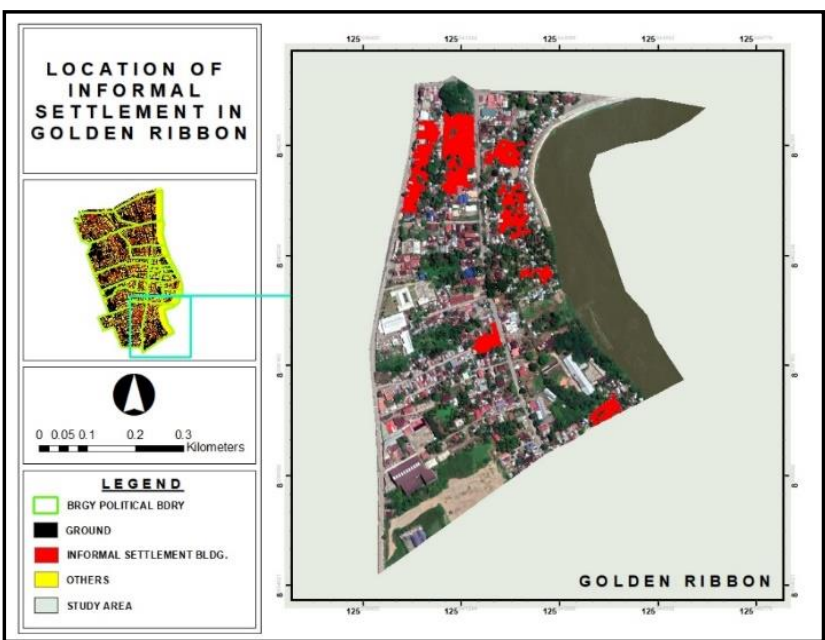

Figure 5. Informal Settlement in Brgy. Golden Ribbon 


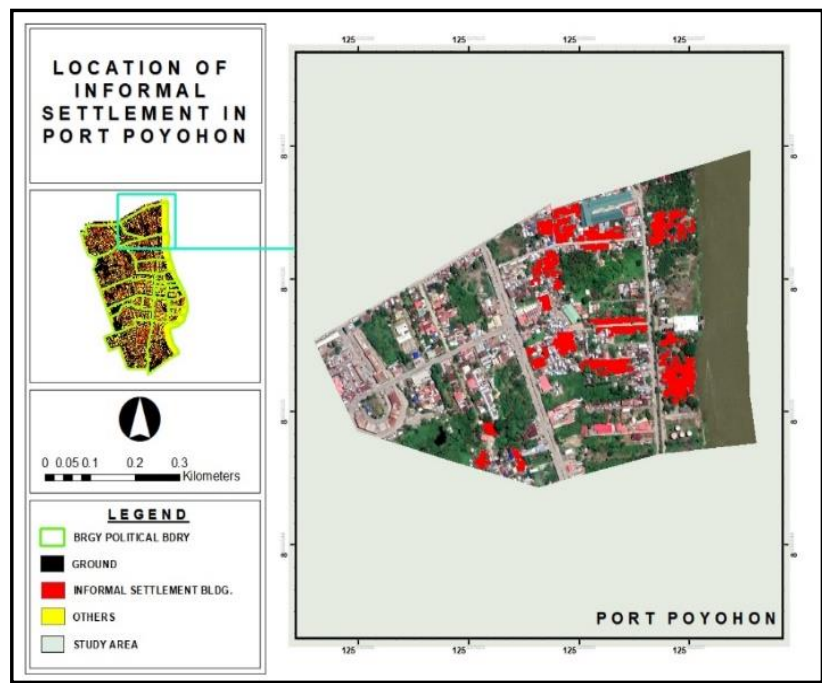

Figure 6. Informal Settlement in Brgy. Port Poyohon

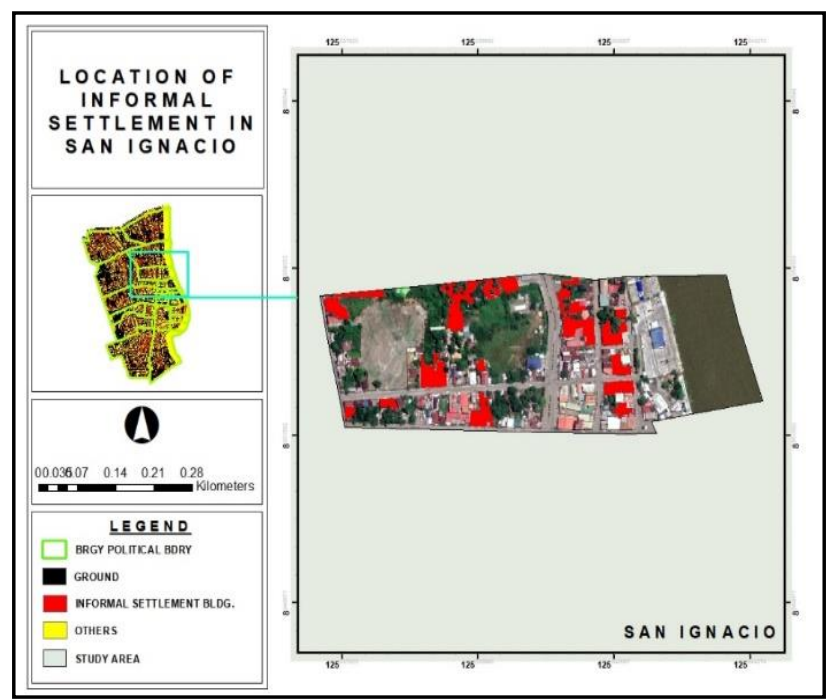

Figure 7. Informal Settlement in Brgy. San Ignacio

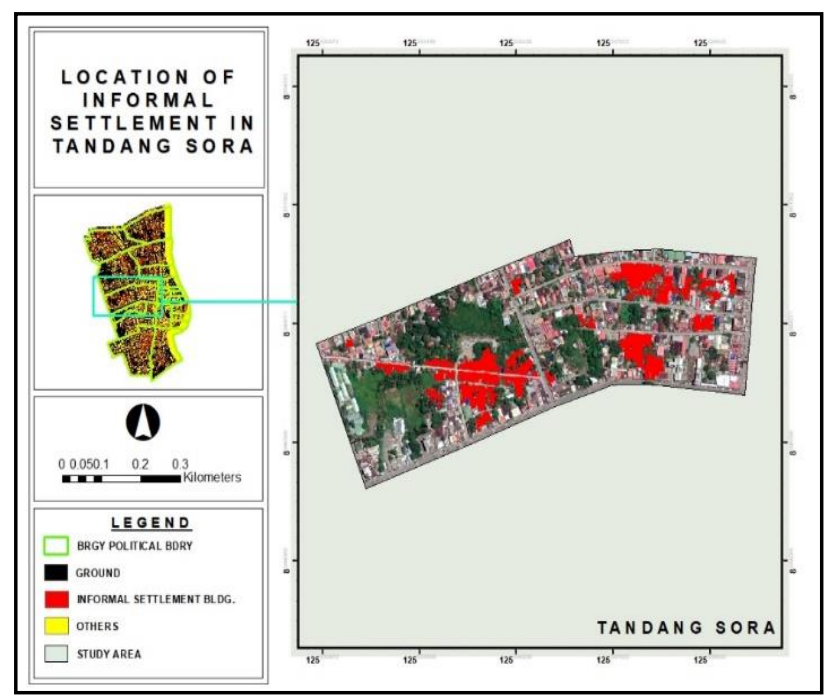

Figure 8. Informal Settlement in Brgy. Tandang Sora

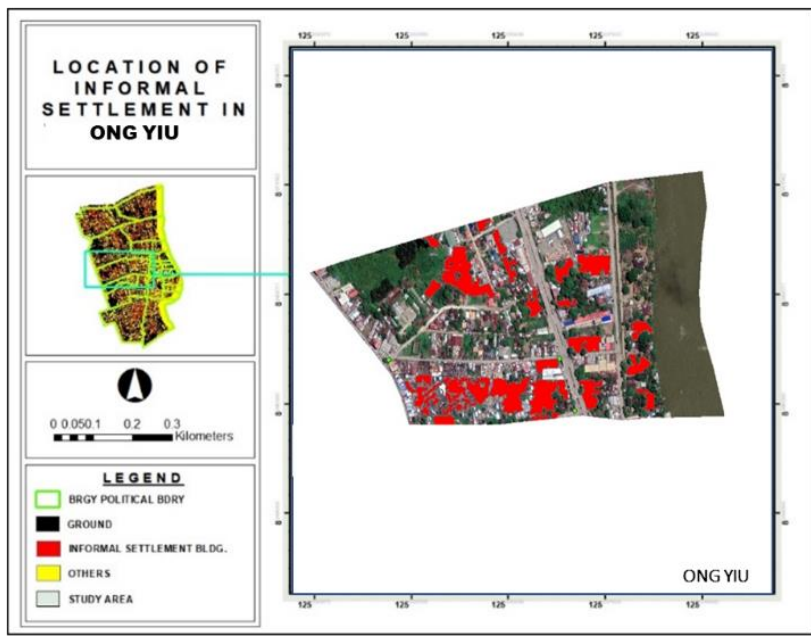

Figure 9. Informal Settlement in Brgy. Ong Yiu

\subsection{Growth of Informal Settlement Areas}

The location of an informal settlement in the other specified year was identified from 2005, 2010, and 2015. The digitized location of an informal settlement in the year 2020 was overlayed to the past year. The area was observed based on the changes of the household.

Figure 10 shows the thematic map area from 2005-2020 and the informal settlement growth in percentage in Holy Redeemer (Table 2). From 2005 to 2010, informal settlements declined to 24\%. Meanwhile, in the years 2010-2015, there was an increase to $14 \%$. Furthermore, from 2015 to 2020 , the occupation had also increased to $13.4 \%$. Generally, from 2005-2020, the informal settlement went down to $1.82 \%$.

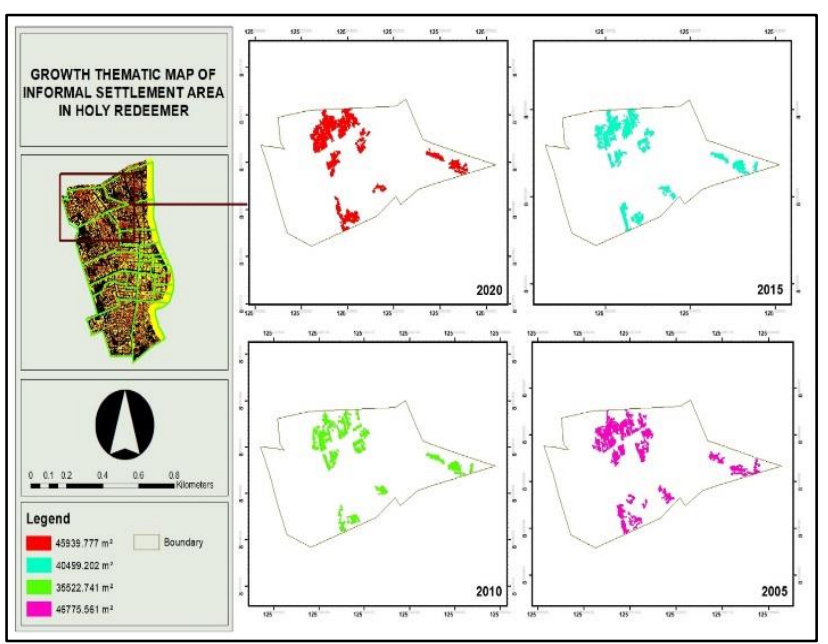

Figure 10. Thematic Map of Brgy. Holy Redeemer from 2005-2020

\begin{tabular}{|c|c|c|c|c|}
\hline $\begin{array}{c}\text { Holy } \\
\text { Redeemer }\end{array}$ & $\begin{array}{c}\mathbf{2 0 0 5 -} \\
\mathbf{2 0 1 0}\end{array}$ & $\begin{array}{c}\mathbf{2 0 1 0 -} \\
\mathbf{2 0 1 5}\end{array}$ & $\begin{array}{c}\mathbf{2 0 1 5}- \\
\mathbf{2 0 2 0}\end{array}$ & $\begin{array}{c}\mathbf{2 0 0 5 -} \\
\mathbf{2 0 2 0}\end{array}$ \\
\hline $\begin{array}{c}\text { Informal } \\
\text { Settlement } \\
\text { Area } \\
\text { Growth }(\%)\end{array}$ & $-24.00 \%$ & $+14.00 \%$ & $+13.41 \%$ & $-1.82 \%$ \\
\hline
\end{tabular}

Table 2. Informal Settlement Growth in Percentage in Brgy. Holy Redeemer 
Figure 11 shows the thematic map area from 2005-2020, and Table 3 shows the informal settlement growth in percentage in Limaha. From 2005 up to the year 2010, the informal settlement descended to $38.00 \%$. There was an increase of $10.00 \%$ from the year 2010-2015. In the year 2015-2020, the growth had declined to $11.87 \%$. Lastly, from 2005 to 2020 , there was a drastic downfall of informal settlements to $40.00 \%$.

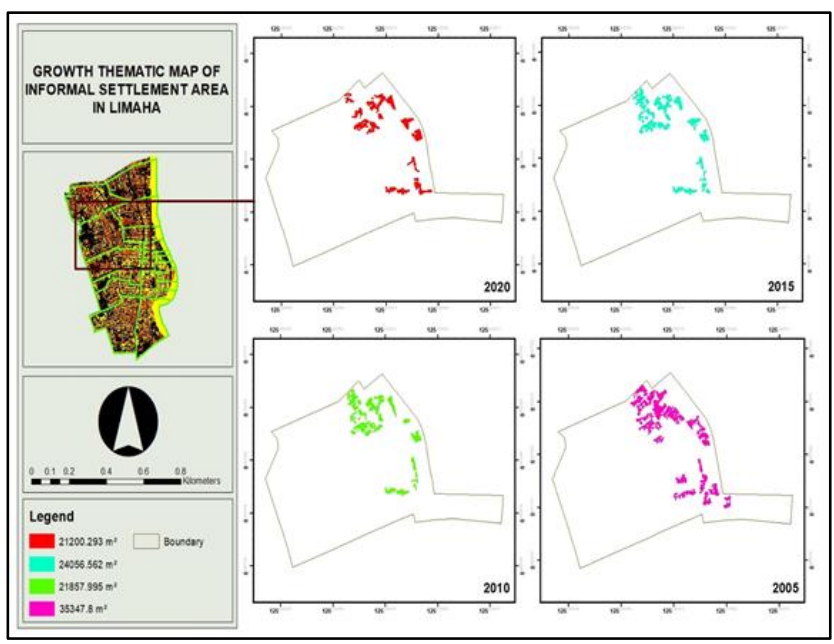

Figure 11. Thematic Map of Brgy. Limaha from 20052020

\begin{tabular}{|c|c|c|c|c|}
\hline Limaha & $\begin{array}{c}\mathbf{2 0 0 5 -} \\
\mathbf{2 0 1 0}\end{array}$ & $\begin{array}{c}\mathbf{2 0 1 0 -} \\
\mathbf{2 0 1 5}\end{array}$ & $\begin{array}{c}\mathbf{2 0 1 5 -} \\
\mathbf{2 0 2 0}\end{array}$ & $\begin{array}{c}\mathbf{2 0 0 5} \\
\mathbf{2 0 2 0}\end{array}$ \\
\hline $\begin{array}{c}\text { Informal } \\
\text { Settlement } \\
\text { Area } \\
\text { Growth } \\
(\%)\end{array}$ & $-38.00 \%$ & $+10.00 \%$ & $-11.87 \%$ & $-40.00 \%$ \\
\hline
\end{tabular}

Table 3. Informal Settlement Growth in Percentage in Brgy. Limaha

Figure 12 shows the thematic map area from 2005-2020 in the Brgy. New Society Village.

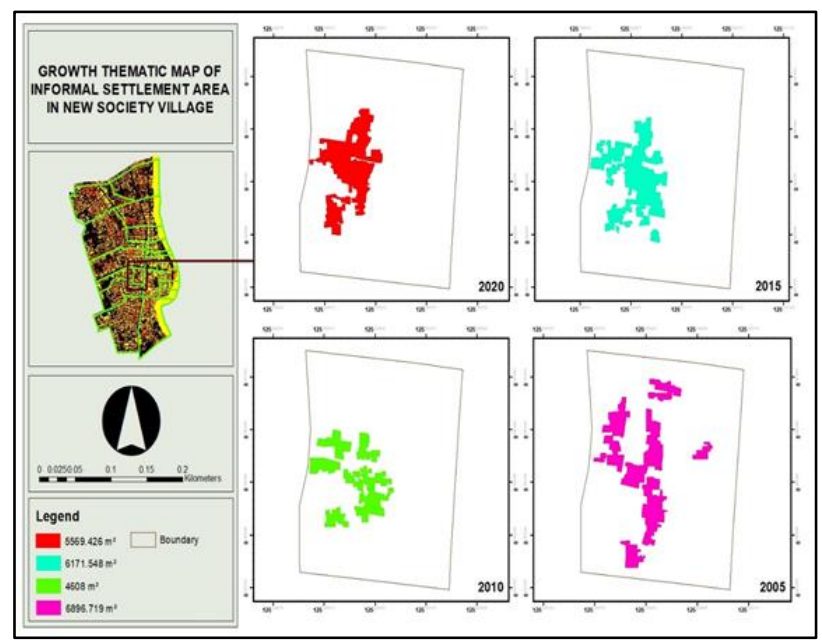

Figure 12. Thematic Map of Brgy. New Society Village from 2005-2020
Table 4 shows the informal settlement growth in percentage was from 2005 up to 2010. There was a decrease in an informal settlement with a percentage of 33.21. On the other side, from 2010 - 2015, there was an increase of 33.90 percent. Furthermore, in the year $2015-2020$, there was a drop to $9.72 \%$. Lastly, in the year 2005 going to 2020, informal settlement declined to $19.24 \%$.

\begin{tabular}{|c|c|c|c|c|}
\hline $\begin{array}{c}\text { New } \\
\text { Society } \\
\text { Village }\end{array}$ & $\begin{array}{c}\mathbf{2 0 0 5 -} \\
\mathbf{2 0 1 0}\end{array}$ & $\begin{array}{c}\mathbf{2 0 1 0 -} \\
\mathbf{2 0 1 5}\end{array}$ & $\begin{array}{c}\mathbf{2 0 1 5 -} \\
\mathbf{2 0 2 0}\end{array}$ & $\begin{array}{c}\mathbf{2 0 0 5 -} \\
\mathbf{2 0 2 0}\end{array}$ \\
\hline $\begin{array}{c}\text { Informal } \\
\text { Settlement } \\
\text { Area } \\
\text { Growth } \\
(\%)\end{array}$ & $-33.21 \%$ & $+33.90 \%$ & $-9.72 \%$ & $-19.24 \%$ \\
\hline
\end{tabular}

Table 4. Informal Settlement Growth in Percentage in Brgy. New Society Village

Figure 13 is the thematic area map of Brgy. Golden Ribbon in the year 2005-2020. On the other hand, Table 5 presents the informal settlement growth in percentage from 2005 to 2010 . The informal settlement decreased to $26.00 \%$. In the year 2010-2015, there was an increase to $17.10 \%$. In the year 2015-2020, it goes down to $4.70 \%$. Generally, within 15 years, from 2005 to 2020, the informal settlement decreased to $17.00 \%$.

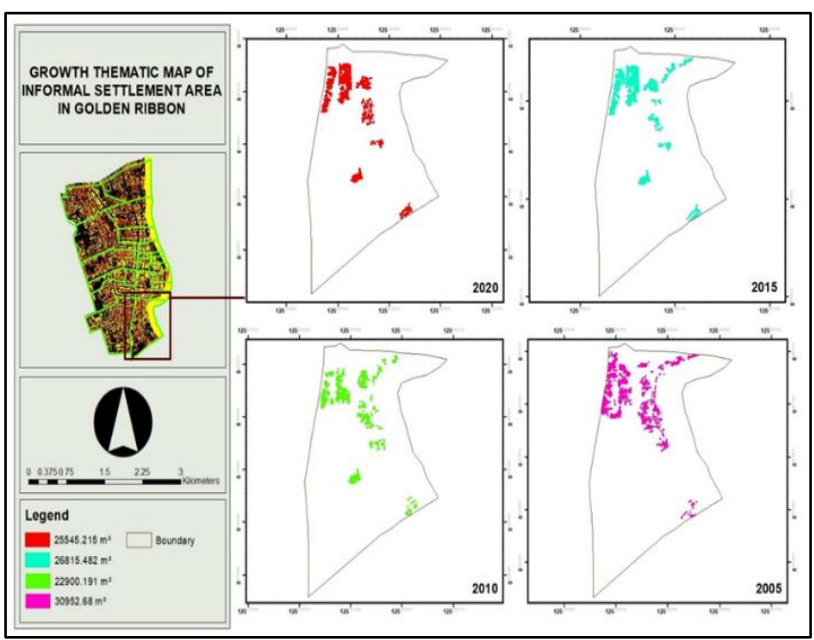

Figure 13. Thematic Map of Brgy. Golden Ribbon from 2005-2020

\begin{tabular}{|c|c|c|c|c|}
\hline $\begin{array}{c}\text { Golden } \\
\text { Ribbon }\end{array}$ & $\begin{array}{c}\mathbf{2 0 0 5 -} \\
\mathbf{2 0 1 0}\end{array}$ & $\begin{array}{c}\mathbf{2 0 1 0 -} \\
\mathbf{2 0 1 5}\end{array}$ & $\begin{array}{c}\mathbf{2 0 1 5 -} \\
\mathbf{2 0 2 0}\end{array}$ & $\begin{array}{c}\mathbf{2 0 0 5 -} \\
\mathbf{2 0 2 0}\end{array}$ \\
\hline $\begin{array}{c}\text { Informal } \\
\text { Settlement } \\
\text { Area }\end{array}$ & $-26.00 \%$ & $+17.10 \%$ & $-4.70 \%$ & $-17.00 \%$ \\
$\begin{array}{c}\text { Growth } \\
(\%)\end{array}$ & & & & \\
\hline
\end{tabular}

Table 5. Informal Settlement Growth in Percentage in Brgy. Golden Ribbon

Port Poyohon thematic area map in the year 2005- 2020 is shown in Figure 14. The growth rate of the informal settlement of people from the year 2005 - 2020 (Table 6). From the year $2005-2010$, the area occupied by informal settlers expanded to $29.23 \%$. Furthermore, from 2010 to 2015 , there was an increase to $4.60 \%$. 
From the year 2015 to 2020 , there was an increase to $39.34 \%$. Lastly, from the year 2005 to 2020 , it has an increased to $88.40 \%$.

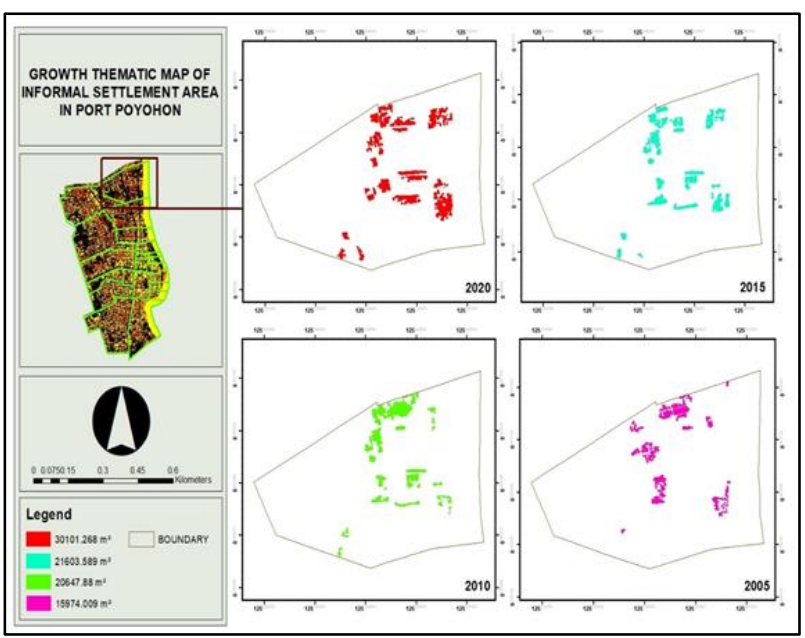

Figure 14. Thematic Map of Brgy. Port Poyohon from 2005-2020

\begin{tabular}{|c|c|c|c|c|}
\hline $\begin{array}{c}\text { Port } \\
\text { Poyohon }\end{array}$ & $\begin{array}{c}\text { 2005- } \\
\mathbf{2 0 1 0}\end{array}$ & $\begin{array}{c}\mathbf{2 0 1 0 -} \\
\mathbf{2 0 1 5}\end{array}$ & $\begin{array}{c}\mathbf{2 0 1 5}- \\
\mathbf{2 0 2 0}\end{array}$ & $\begin{array}{c}\mathbf{2 0 0 5}- \\
\mathbf{2 0 2 0}\end{array}$ \\
\hline $\begin{array}{c}\text { Informal } \\
\text { Settlement } \\
\text { Area }\end{array}$ & $+29.23 \%$ & $+4.60 \%$ & $+39.34 \%$ & $+88.40 \%$ \\
$\begin{array}{c}\text { Growth } \\
(\%)\end{array}$ & & & & \\
\hline
\end{tabular}

Table 6. Informal Settlement Growth in Percentage in Brgy. Port Poyohon

San Ignacio thematic area map in the year 2005- 2020 is shown in Figure 15. There was a $50.23 \%$ increase in residence from 2005-2010 (Table 7). From the year 2010 to 2015, there was a decline of $25.22 \%$. Furthermore, from 2015 to 2020 , there was a drastic increase of $79.40 \%$. Generally, in the year 2005 to 2020 , the informal settlement increased to $101.53 \%$.

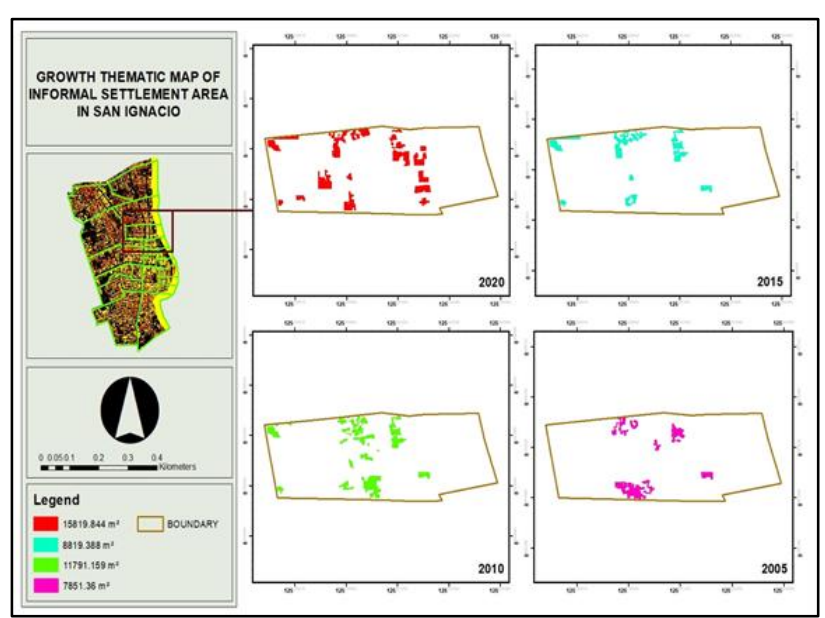

Figure 15. Thematic Map of Brgy. San Ignacio from 2005-2020

\begin{tabular}{|c|c|c|c|c|}
\hline $\begin{array}{c}\text { San } \\
\text { Ignacio }\end{array}$ & $\begin{array}{c}\mathbf{2 0 0 5 -} \\
\mathbf{2 0 1 0}\end{array}$ & $\begin{array}{c}\mathbf{2 0 1 0 -} \\
\mathbf{2 0 1 5}\end{array}$ & $\begin{array}{c}\mathbf{2 0 1 5 -} \\
\mathbf{2 0 2 0}\end{array}$ & $\begin{array}{c}\mathbf{2 0 0 5 -} \\
\mathbf{2 0 2 0}\end{array}$ \\
\hline $\begin{array}{c}\text { Informal } \\
\text { Settlement } \\
\text { Area }\end{array}$ & $+50.23 \%$ & $-25.22 \%$ & $+79.40 \%$ & $+101.53 \%$ \\
$\begin{array}{c}\text { Growth } \\
(\%)\end{array}$ & & & & \\
\hline
\end{tabular}

Table 7. Informal Settlement Growth in Percentage in Brgy. San Ignacio

Figure 16 shows the thematic map area from 2005-2020 in Brgy. Tandang Sora. Table 8 shows the informal settlement growth rate from 2005 to 2010. There was a significant increase in the informal settlement, $107.34 \%$. From 2010 to 2015 , there was a decrease to $0.81 \%$ in the informal settlement population. There was a $35.57 \%$ increase from 2015-2020 and a $178.52 \%$ increased growth rate from 2005-2020 of the informal settlement in Tandang Sora.

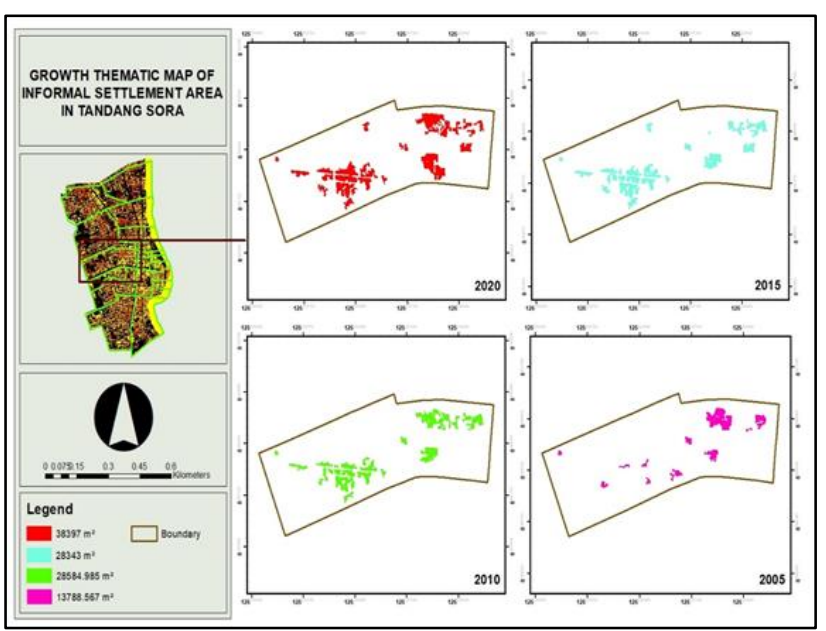

Figure 16. Thematic Map of Brgy. Tandang Sora from 2005-2020

\begin{tabular}{|c|c|c|c|c|}
\hline $\begin{array}{c}\text { Tandang } \\
\text { Sora }\end{array}$ & $\begin{array}{c}\mathbf{2 0 0 5}- \\
\mathbf{2 0 1 0}\end{array}$ & $\begin{array}{c}\mathbf{2 0 1 0 -} \\
\mathbf{2 0 1 5}\end{array}$ & $\begin{array}{c}\mathbf{2 0 1 5}- \\
\mathbf{2 0 2 0}\end{array}$ & $\begin{array}{c}\mathbf{2 0 0 5}- \\
\mathbf{2 0 2 0}\end{array}$ \\
\hline $\begin{array}{c}\text { Informal } \\
\text { Settlement } \\
\text { Area }\end{array}$ & $+107.34 \%$ & $-0.81 \%$ & $+35.57 \%$ & $+178.52 \%$ \\
$\begin{array}{c}\text { Growth } \\
(\%)\end{array}$ & & & & \\
\hline
\end{tabular}

Table 8. Informal Settlement Growth in Percentage in Brgy. Tandang Sora

Figure 17 shows the thematic map area from 2005-2020 in the Brgy. Ong Yiu. Table 9 shows the informal settlement growth from 2005-2020. From the year 2005 to 2010, the informal settlement decreased to $18.90 \%$. While in the year 2010 to 2015 , there was an increase of $28.06 \%$. Moreover, in the year 2015 to 2020 , there was a decrease of $5.88 \%$. Overall, from 2005 to 2020 , there was a drop of $2.32 \%$. 


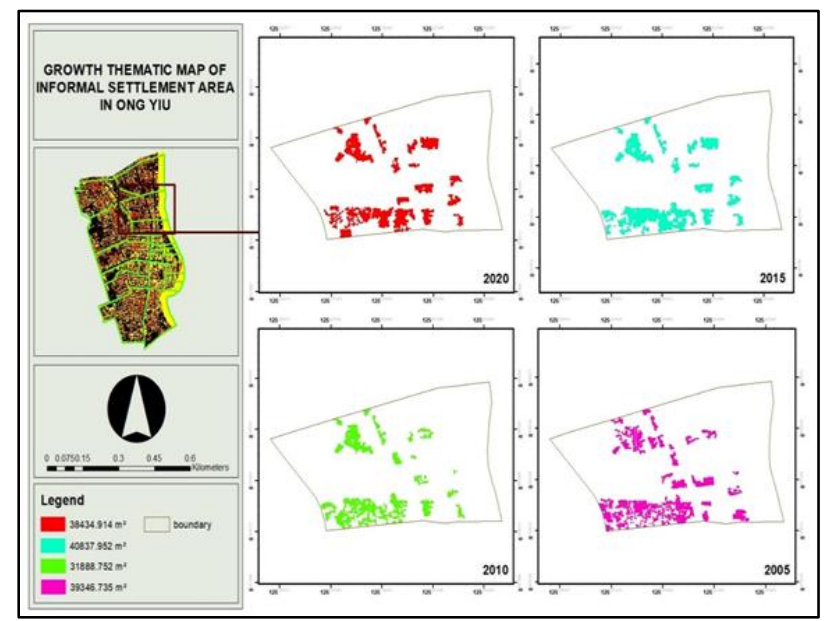

Figure 17. Thematic Map of Brgy. Ong Yiu from 20052020

\begin{tabular}{|c|c|c|c|c|}
\hline Ong Yiu & $\begin{array}{c}\mathbf{2 0 0 5 -} \\
\mathbf{2 0 1 0}\end{array}$ & $\begin{array}{c}\mathbf{2 0 1 0 -} \\
\mathbf{2 0 1 5}\end{array}$ & $\begin{array}{c}\mathbf{2 0 1 5 -} \\
\mathbf{2 0 2 0}\end{array}$ & $\begin{array}{c}\mathbf{2 0 0 5}- \\
\mathbf{2 0 2 0}\end{array}$ \\
\hline $\begin{array}{c}\text { Informal } \\
\text { Settlement } \\
\text { Area } \\
\text { Growth } \\
(\%)\end{array}$ & $-18.90 \%$ & $+28.06 \%$ & $-5.88 \%$ & $-2.32 \%$ \\
\hline
\end{tabular}

Table 9. Informal Settlement Growth in Percentage in Brgy. Ong Yiu

Figure 18 shows the location of the informal settlements of the eight (8) barangays in Butuan City.

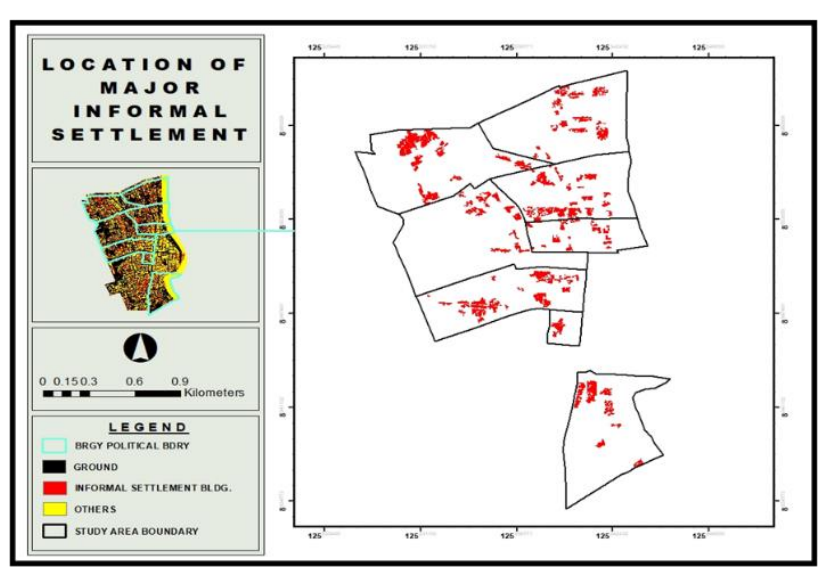

Figure 18. Location of the Major Informal Settlements

Figure 19 reveals the rate of change of the eight (8) barangays) in Butuan City. On the other hand, the most common reason for the informal settlement is that they do not own a piece of land to settle formally.

The summary of the overall growth of areas of central informal settlements locations in Butuan City for each year intervals 20052010, 2010-2015, and 2015-2020 (Table 10 and Figure 20). In five-year intervals, there was a change of area occupied by informal settlers, which may be increased or decreased.

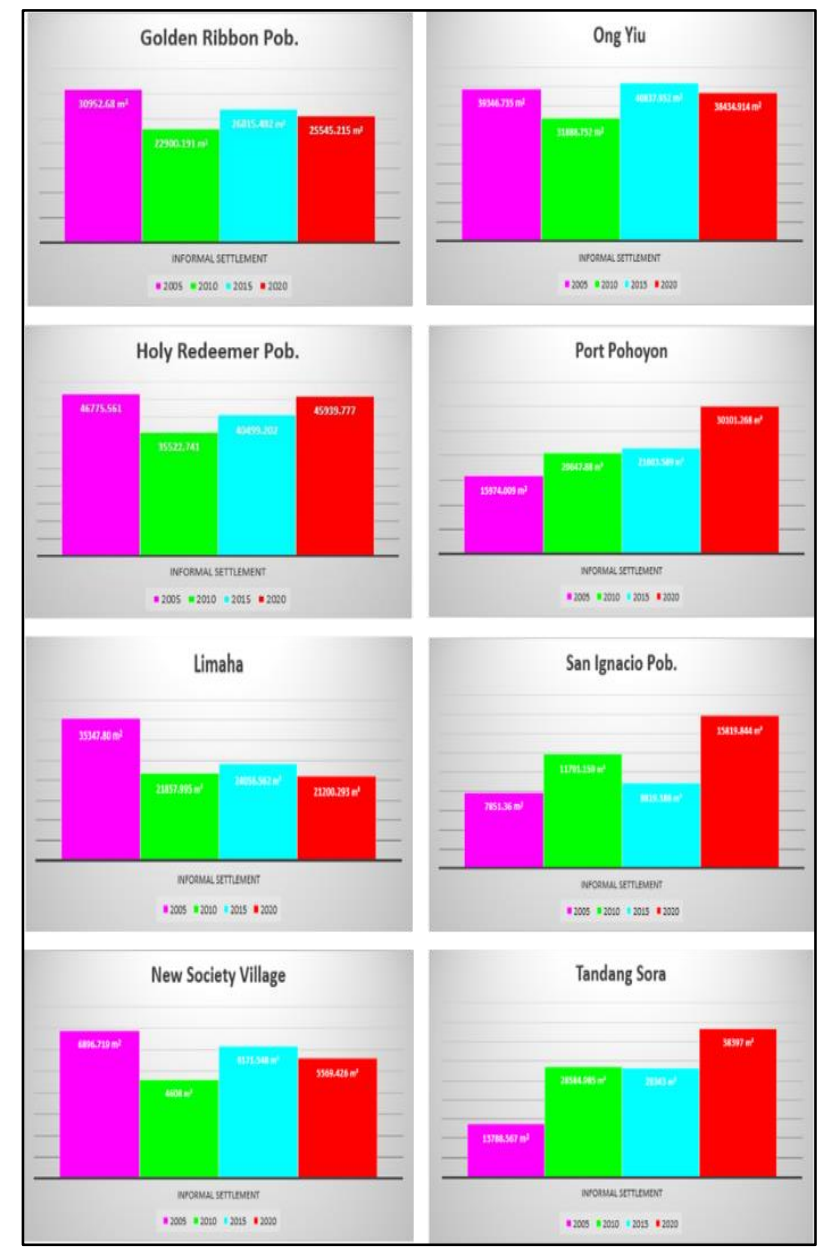

Figure 19. Rate of change of Informal Settlements of the eight (8) barangays in Butuan City Butuan City

\begin{tabular}{|c|c|c|}
\hline BARANGAY & $\mathbf{2 0 0 5}$ & $\mathbf{2 0 1 0}$ \\
\hline Tandang Sora & $13788.57 \mathrm{~m}^{2}$ & $28584.98 \mathrm{~m}^{2}$ \\
\hline San Ignacio & $7851.36 \mathrm{~m}^{2}$ & $11791.16 \mathrm{~m}^{2}$ \\
\hline Port Pohoyon & $15974.01 \mathrm{~m}^{2}$ & $20647.88 \mathrm{~m}^{2}$ \\
\hline Ong Yiu & $39346.73 \mathrm{~m}^{2}$ & $31888.75 \mathrm{~m}^{2}$ \\
\hline New Society & $6896.72 \mathrm{~m}^{2}$ & $4608.00 \mathrm{~m}^{2}$ \\
\hline Limaha & $35347.80 \mathrm{~m}^{2}$ & $21857.99 \mathrm{~m}^{2}$ \\
\hline Holy Redeemer & $46775.56 \mathrm{~m}^{2}$ & $35522.74 \mathrm{~m}^{2}$ \\
\hline Golden Ribbon & $30952.68 \mathrm{~m}^{2}$ & $22900.19 \mathrm{~m}^{2}$ \\
\hline Total Area & $196933.43 \mathrm{~m}^{2}$ & $177801.70 \mathrm{~m}^{2}$ \\
\hline
\end{tabular}

\begin{tabular}{|c|c|c|}
\hline BARANGAY & $\mathbf{2 0 1 5}$ & $\mathbf{2 0 2 0}$ \\
\hline Tandang Sora & $28343.00 \mathrm{~m}^{2}$ & $38397.00 \mathrm{~m}^{2}$ \\
\hline San Ignacio & $8819.39 \mathrm{~m}^{2}$ & $15819.84 \mathrm{~m}^{2}$ \\
\hline Port Pohoyon & $21603.59 \mathrm{~m}^{2}$ & $30101.27 \mathrm{~m}^{2}$ \\
\hline Ong Yiu & $40837.95 \mathrm{~m}^{2}$ & $38434.91 \mathrm{~m}^{2}$ \\
\hline New Society & $6171.55 \mathrm{~m}^{2}$ & $5569.45 \mathrm{~m}^{2}$ \\
\hline Limaha & $24056.56 \mathrm{~m}^{2}$ & $21200.29 \mathrm{~m}^{2}$ \\
\hline Holy Redeemer & $40499.20 \mathrm{~m}^{2}$ & $45939.78 \mathrm{~m}^{2}$ \\
\hline Golden Ribbon & $26815.48 \mathrm{~m}^{2}$ & $25545.21 \mathrm{~m}^{2}$ \\
\hline Total Area & $197146.72 \mathrm{~m}^{2}$ & $221007.74 \mathrm{~m}^{2}$ \\
\hline
\end{tabular}

Table 10. Total Areas of Major Informal Settlements 


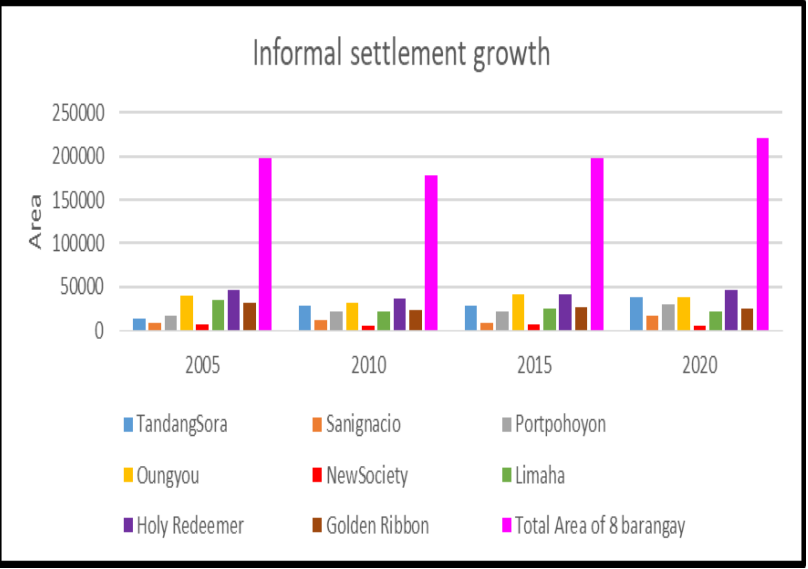

Figure 20. Overall total growth of areas of major informal settlements

Figure 21 displays the growth rate in a 5-year interval. The growth rate of the areas was computed to excel using the Equation 1 formula. From 2005 to 2010, the area decreased up to $9.71 \%$. In 2010-2015, the area increased up to $10.88 \%$. Moreover, in 2015-2020, the area was increased up to $12.10 \%$. The results show that in 2005-2020, for 15 years, the area increased up to $9.74 \%$, a total of $19,172.88 \mathrm{~m}^{2}$.

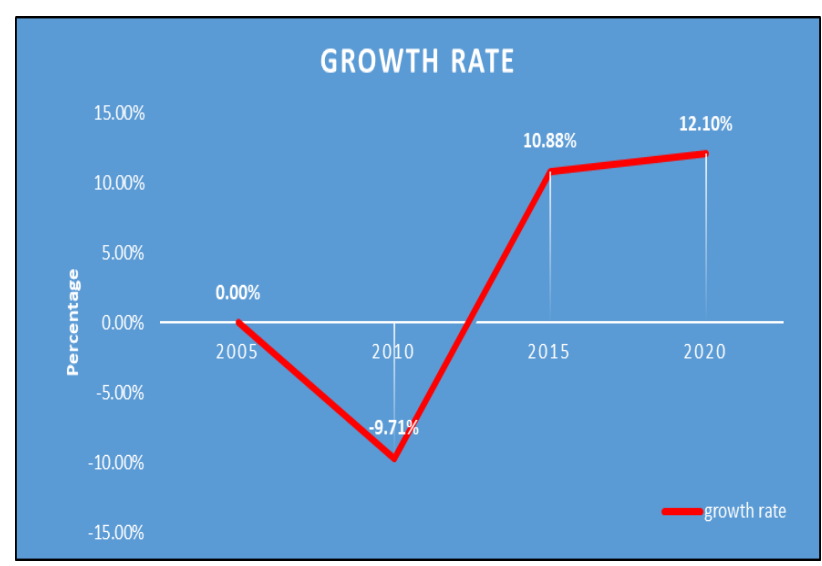

Figure 21. Growth rate in a 5-year interval

\section{CONCLUSION}

The machine learning algorithm, precisely the Support Vector Machine (SVM) algorithm in E-cognition developer, helps locate the possible major informal settlement buildings areas. It lessens the time when it comes to manual digitizing. Remote Sensing and GIS-based techniques help in validating the possible informal settlement areas.

The results of the study reveal that the significant informal settlement in the study area increased. Among the eight (8) identified barangays, Tandang Sora ranked as the highest informal settlement's growth from 2005 to 2020 . Its area increased up to $178.52 \%$, a total of $24608.43 \mathrm{~m}^{2}$.

\section{REFERENCES}

Asm Amanullah, Asm Amanullah, "Access to Land and Location of Informal Settlements in Tacloban City, Philippines", p. 1, January 2011.

Edith Rosario Jimenez-Huerta, "Informal Settlements", p. 4, 15 April 2019

Navarro, Ma. Kresna, Almaden, Catherine Roween "The Cost of Misguided Urbanization: The Case of Informal Settlements in Butuan City, Philippines", Pages 6-7, September 1, 2014.

M. Baatz, U. Benz, S. Dehghani, M. Heynen, A. Höltje, P. Hofmann, I. Lingenfelder, M. Mimler, M. Sohlbach, M. Weber and G. Willhauck, Ecognition User Guide 3: Object Oriented Image Analysis, Munich, Germany, 2001

Nicolas Baghdadi, Mehrez Zribi, "Optical Remote Sensing of Land Surface Techniques and Methods : 7-Digital Terrain Models Derived from Airborne LiDAR Data", Pages 299-319, 2017.

Patrick Campbell, "How To Use The Growth Rate Formula \& 3 Different Ways To Calculate Growth Rate”, Aug. 22, 2020. 